\title{
Risk management of leasing companies
}

\author{
Elena Kouzmina ${ }^{1, *}$, and Vladimir Okrepilov ${ }^{2}$ \\ ${ }^{1}$ Higher School of Economics, St. Petersburg; Russia \\ ${ }^{2}$ Institute for Problems of Regional Economics RAS, Serpukhovskaya street, 38, Sankt-Peterburg, \\ 190013, Russia
}

\begin{abstract}
The need to improve the investment climate and form a new efficient system of economic relations requires the use of new economic mechanisms, among which leasing is one of the most effective for the development of the real economy. The paper deals with the risk management problems of leasing companies and leasing projects. It discusses the activities of specialized leasing companies and methods of risk management of leasing transactions based on basic risk management processes in project management, analyzes various types of risks associated with lessors, discusses methodological approaches to managing risks of leasing companies in general, and economic and mathematical methods for assessing risks of default for lessees. An econometric model has been created that allows predicting confidence in the payment of lease payments or the default of the lessee. The obtained model excludes the subjective methods for assessing the potential client's solvency and is less labor-intensive in comparison with the scoring model and the method of expert assessment.
\end{abstract}

\section{Introduction}

International experience proves the extremely high efficiency of such a financial and credit instrument as leasing, the use of which can accelerate the economic development of a country. Unfortunately, the potential of this mechanism for attracting capital is still not widely used in Russia, while the expansion of the leasing services market can play a significant role in increasing the efficiency of the economy and accelerating the renewal of industrial equipment and vehicles of the country's enterprises [1]. In this regard, one of the most urgent tasks is the problem of managing the risks of specialized leasing companies, whose main activity is related to leasing transactions, and in whose activities, there is a high degree of uncertainty. If we also take into account the insufficient development of the legislative base and its inconsistency associated with international economic sanctions, instability of the financial market and banking system, we can conclude about a wide range of risks of leasing companies and the need to form a methodological basis for assessing and managing risks of leasing companies.

Note that any leasing transaction is a long-term project, because it has all the properties of a project according to the theory of project management, namely, the uniqueness and

\footnotetext{
* Corresponding author: ev.kuzmina@hse.ru
} 
singularity of goals and works, coordinated implementation of interrelated works, focus on the achievement of final goals, limited time, limited resources. Thus, we can talk about risk management of leasing projects.

\section{Materials and Methods}

General methods of risk management of investment projects are also applicable to leasing transactions. It should be noted that risk is a very complex and multidimensional category. In reference to financial assets, the following risk interpretation is used: the "riskiness" of an asset is characterized by the degree of income (or profitability) variability that this asset can bring to its owner. It is also said that there are two risks - negative and positive (positive deviation of profitability from a certain base level).

The need to manage the risks of investment projects has been obvious to investors for a long time, but for a long time, the management process was carried out intuitively, by introducing individual risk minimization tools. A clear understanding and formulation of the problem became possible relatively recently, thanks to the development of an independent science - Risk management. The presence of a project risk management system is recognized as a prerequisite for the implementation of investment projects. Nowadays, there are a number of authoritative international standards in risk management, widely used in the practice of risk assessment of investment projects, such as FERMA, COSO, PMBOK. These standards establish the importance of risk management as a mandatory component of the effectiveness of an investment project.

Modern conditions of the leasing business are very complex, and this encourages the top management of leasing companies to introduce modern methods of risk management in everyday practice. At the same time, it is necessary to operate with basic concepts of the general theory of project risk management: a risky event, a project risk, the risk probability, the consequences of a risk occurrence. The key is the concept of risk magnitude. This indicator combines the risk probability and the consequences of its occurrence. It is calculated as the product of the probability of a risk event occurrence and its consequences. Risk management of a leasing transaction should include all six basic processes: risk management planning, risk identification, qualitative risk assessment, quantitative risk assessment, risk response planning, monitoring and control of risks.

Let us now consider the specific features of the leasing transactions, which may affect the approaches to risk management. The main specificity of a major leasing transaction with factory equipment, sea, river or airborne vehicle is that it combines at least three parties - the lessee, the lessor, and the plant. Most often, there is the fourth party - the bank lending to the lessor, as well as the fifth - the insurer. The successful completion of the project can be considered the fact of full payment by the lessee of all lease payments and the purchase of the leased object at residual value or return it to the lessor, depending on the terms of the contract. Therefore, the "locomotive" of the entire project is the lessee, and the success of the project mainly depends on the success of the implementation of its activities. The risks of the leasing company (the lessor) are mainly related to the possibility that it does not receive the full amount of the lease payments, and, in some cases, the loss of the object.

The process of planning the risk management of a leasing project by the leasing company involves making decisions about methods that it will use to manage its risks. These decisions may concern the choice of methodology, organization of business processes, data sources for risk identification, personnel and information support of risk management procedures, monitoring procedures, time intervals for analyzing a situation. Consequently, the leasing company must be able to control the activities of the lessee, and it has such an opportunity. According to the Russian legislation, the lessor has the right to 
send to the lessee requests for information necessary for financial control in written form, and the lessee is obliged to satisfy such requests.

The process of identifying the risks of a leasing project determines which risks are likely to affect the project. The result of this process should be a special document called the "Risk Register". The process of identifying risks includes the identification of risks, the identification of signs and conditions under which relevant risk events may occur, and the classification of risks.

\section{Discussion}

The risk classification of the leasing project began to interest researchers back in the 1980s. The pioneers in this direction were H. Levy and M. Sarant, who, within their work, drew parallels between leasing and credit transactions. As a result, two key risks of leasing companies were formulated: credit and interest rate risks. The first implies the lessee's inability to fulfill its contractual obligations due to internal financial instability. The second involves possible changes in interest rates on loan financing, which may later exceed the rates under the lease agreement. In the future, a number of researchers proposed the following classification of risks for leasing companies: credit, interest rate, price, currency, legal, tax, and liquidity risks [2-4]. Below is the risk classification of leasing companies.

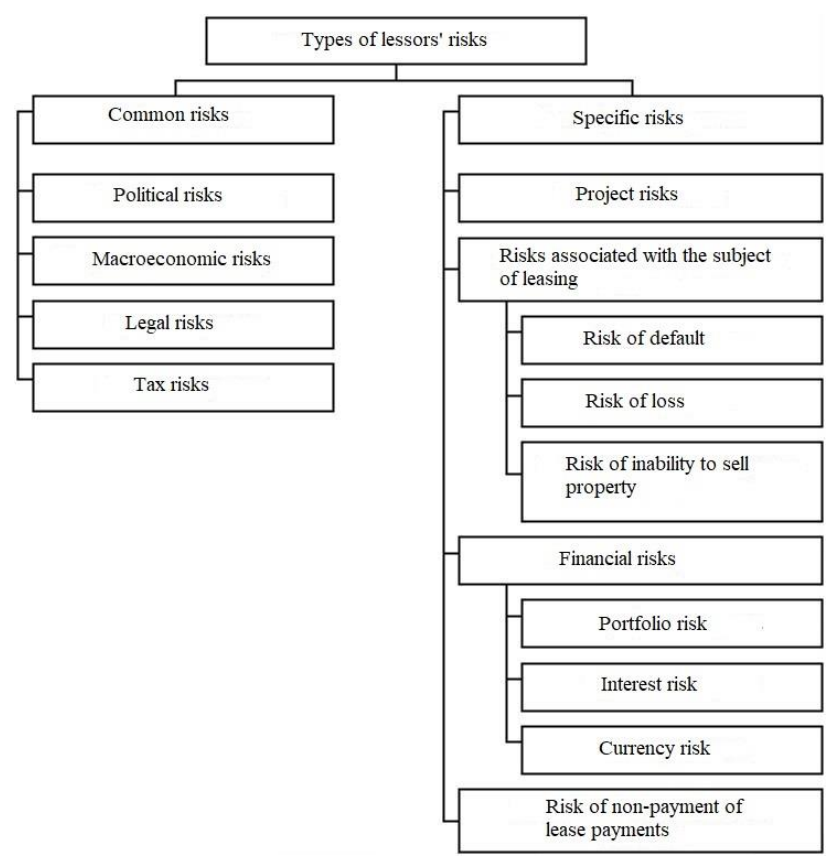

Fig. 1. Risk classification of a leasing company.

The group of external risks includes the following: legal and political risks, currency and interest risks, social and environmental risks, marketing risk and client insolvency risk. The latter implies the impossibility of the lessee making payments under the lease agreement. This risk can be minimized by careful analysis of the financial situation of the lessee's company, limiting the amount of the contract, receiving third-party guarantees, and insuring the client's insolvency risk.

The purpose of the risk identification stage is to find, list, and characterize all types of risk that may affect the implementation of the leasing project. 
The process of qualitative risk assessment of a leasing project is the process of determining the likelihood of identified risks and their consequences for the leasing project. In this case, risk managers can apply a relative scale on which the probability is designated descriptively or on which a certain digital value corresponds to probability.

The used methods should be described in the corporate document of the leasing company, the name of which, for example, may sound like "Guidelines for risk assessment". The use of qualitative analysis methods helps to partially avoid the uncertainties that are often found in a leasing project. Note that during the life cycle of a leasing project, risks must be re-assessed constantly.

The process of quantitative risk assessment of a leasing project is the process of determining the likelihood of risks occurrence and the effects of the consequences of risks on a project. Note that a quantitative analysis is made in relation to not all risks, but only those of them that were qualified as the most important in the qualitative risk analysis. In the quantitative analysis, the effect of risk events is assessed, and weights are assigned to risks (numerical rating).

Planning a response to the risks of a leasing project is the process of developing methods to reduce the negative impact of risks on a leasing project. The main methods of responding to risks include avoidance (risk rejection), risk transfer (distribution), risk minimization (control and prevention), and risk acceptance.

Monitoring and controlling risks of a leasing project is the process of identifying, analyzing new risks, planning measures to respond to risks, constantly tracking identified risks and those risks that are on the watch list, and also checking and executing measures to respond to risks and assessing their effectiveness.

\section{Results}

At the moment, the situation in the leasing services market has reached such a phase of development that there is a need to create an entire risk management complex for a leasing company. Studies conducted by scientists have shown that credit risk is the most significant $[5,6]$. Considering the specifics of leasing companies, credit risks are conditionally divided into three categories (Table 1).

Table 1. Types of credit risk of a leasing company.

\begin{tabular}{|l|l|}
\hline Lessee default risk & $\begin{array}{l}\text { inability or unwillingness of the lessee to pay leasing } \\
\text { payments }\end{array}$ \\
\hline Liquidity risk & late payment of leasing payments by the lessee \\
\hline Supplier default risk & $\begin{array}{l}\text { inability or unwillingness of the supplier to deliver the } \\
\text { leased property according to the contract }\end{array}$ \\
\hline
\end{tabular}

One of the most important tasks in assessing the risk of the lessor is to calculate the PD (probability of default) of the lessee. At the moment, there are several ways to calculate it [7-9]. The economists were interested in the calculation of the probability of default long before the widespread use of leasing. The first studies in this area began to appear from the mid-60s of the last century. Research of assessment of business failures, such as onedimensional and multidimensional models, developed by Beaver in 1967 and Altman in 1967, used certain financial ratios. They became one of the first significant works in this field. While Beaver studied 14 financial reports, Altman used Multiple Discriminant Analysis (MDA) to solve the inconsistency problem associated with Beaver's onedimensional analysis and to present a more complex financial profile of the studied companies. Thus, multiple discriminant analysis was used for many years by various authors, such as Edmister and Dekin, Taffler and Bilderbeek, Micha and Lussier, as well as in subsequent works of Altman himself [10]. 
Analytical methods include cluster analysis based on financial ratios. It was represented in the works of Altman in 1968. The purpose of cluster analysis is to calculate the creditworthiness index of the lessee company. Positive aspects of this method are the high objectivity of the results with relatively low labor costs. The disadvantages include the subjectivity of the choice of basic indicators and the need to adjust the weight ratios when analyzing Russian companies, taking into account regional and industry conditions of operation.

The expert method, in contrast to the analytical one, is not tied to the financial statements of a company, but is characterized by instability and subjective results. In addition, it takes much more time.

Other methods based on capitalization in the stock market, the volume of the lessee's debts to creditors, and information on defaults of the lessee's company over a long period of time are difficult to implement due to the underdevelopment of the stock market in Russia and the lack of necessary information in the statistical offices. Next, we consider the economic and mathematical methods for assessing the risk of default of the lessee.

Default is defined as the inability of the borrower to fulfill its financial obligations. In our case, default means the company's inability to pay the amounts specified in the leasing agreement to the lessor on time. Thus, PD (probability of default) will be a coefficient determining the rating of each potential lessee. As a software tool for econometric analysis, it makes sense to use the Stata universal statistical package by StataCorp. The econometric model is based on financial ratios from different categories of financial assessment of an enterprise.

The model allows for the initial analysis of a potential lessee, based on the financial statements of the company. This method has advantages due to the transparency and readiness of the primary data.

It is necessary to calculate three groups of financial indicators:

- liquidity ratios;

- ratio of own funds;

- indicators of turnover and profitability.

When analyzing, one should take into account that the past and present of the company of the potential lessee is studied, and the goal is to draw up and justify assumptions about its future, about financial stability and solvency for the duration of the lease agreement. This model is a method of calculating the six main ratios of the above groups, its own specific weight is assigned to each coefficient. Next, the summation of the ratios, taking into account the given weight. The resulting number belongs to one of three numerical segments that determine membership in one of the three groups - the lessee's creditworthiness classes:

First class - the conclusion of a lease agreement is recommended;

Second class - the discussion of certain conditions under the contract before signing;

Third class - the conclusion of the contract is not recommended.

Next, there is a comparison of initial data that takes into account the level of solvency of lessee companies with their distribution by solvency classes according to the scoring model and building an econometric model, which allows predicting confidence in paying the leasing payments or default of the lessee with a probability of 95 percent.

\subsection{Regression model for assessing the default risk of a client of a leasing company}

To build a regression model, 7 most appropriate ratios belonging to different categories were used as variables in order to analyze how they influence the lessor's decision to enter into a contract: 
A) from the category of solvency ratios:

$$
\text { Capital ratio }=\frac{\text { Loaned funds }}{\text { Own funds }}
$$

The capital ratio describes the financial ratio of own funds of the company to loaned ones. This ratio provides the extent to which the company's activities are financed at the expense of the owner compared with the funds of the lender.

$$
\begin{gathered}
\text { Financial leverage }=\frac{\text { Debt issues }}{\text { Company assets }} \\
\text { Interest coverage ratio }=\frac{\text { EBITDA }}{\text { Interest payments }}
\end{gathered}
$$

The interest coverage ratio (ICR) shows the company's ability to service its loaned funds. A high ICR value indicates a stable position of the company, and a low value indicates a high probability of bankruptcy.

B) from the category of profitability ratios:

$$
\begin{gathered}
\text { Return on equity }=\frac{\text { Net profit }}{\text { Net worth }} \\
\text { Return on sales }=\frac{\text { Sales profit }}{\text { Sales revenue }} * 100 \%
\end{gathered}
$$

C) from the category of liquidity ratios:

$$
\text { Quick liquidity ratio }=\frac{\begin{array}{c}
\text { Short-term financial investments +Monetary assets } \\
+ \text { Short-term receivables }
\end{array}}{\text { Current liabilities }}
$$

D) from the category of ratios reflecting the company's activities:

$$
\text { Inventory turnover }=\frac{\text { Stocks }}{\text { Sales volume }} * 365
$$

Let's take a period equal to one year. Using the Stata software package, we create new variables according to the specified formulas. Table 1 shows the names of the new variables and the expected interdependence with the target indicator - PD or the risk of default of the potential client.

Table 2. Names of the model's regressors.

\begin{tabular}{|l|c|c|}
\hline \multicolumn{1}{|c|}{ Ratio } & Name of variable & Dependence with PD \\
\hline Capital ratio & Kapital & + \\
\hline Financial leverage & LRL & + \\
\hline Interest coverage ratio & ICR & - \\
\hline Return on equity & ROE & - \\
\hline Return on sales & ROS & - \\
\hline Quick liquidity ratio & Qli & - \\
\hline Inventory turnover & Turnover & + \\
\hline
\end{tabular}

The sign "+" in the third column indicates the direct proportional dependence of the ratio with the desired indicator, and the sign “_." indicates inverse dependence. 
Liquidity ratios indicate a company's ability to pay short-term debts and, as a rule, higher liquidity equals a lower probability of default.

Solvency ratios indicate a company's ability to pay long-term debts.

Profitability ratios show the company's ability to make a profit, and the higher this ability, the smaller the PD.

Activity ratio shows the degree of efficiency of use of various resources by the company.

All formed variables are ordinal. The dependent variable is fictitious or Dummy variable, which takes only values 0 and 1 , where 0 means no sign of default of the lessee, and 1 - the presence of obvious signs of default. Independent variables have a normal Gaussian distribution, which allows us to use linear regression to build a model.

Next, we will directly build an econometric model for the dependence of the company's PD index on its financial ratios. The following are the three most successful variations of linear models of the dependence of the default probability on the company's financial indicators.

$$
\begin{gathered}
\mathrm{PD}=\beta_{1} * \text { kapital }+\beta_{2} * \operatorname{lrl}+\beta_{3} * \mathrm{icr}+\beta_{4} * \text { roe }+\beta_{5} * \text { ros }+\beta_{6} * \mathrm{qli}+\beta_{7} \text { turnover } \\
\mathrm{PD}=\beta_{1} * \text { kapital }+\beta_{2} * \mathrm{icr}+\beta_{3} * \text { roe }+\beta_{4} * \mathrm{qli}+\beta_{5} \text { turnover } \\
\mathrm{PD}=\beta_{1} * \operatorname{lrl}+\beta_{2} * \text { roe }+\beta_{3} * \text { ros }+\beta_{4} * \mathrm{qli}
\end{gathered}
$$

The main ratios and statistics of the models are presented in table 3.

Table 3. Results of assessments of linear regression models.

\begin{tabular}{|l|c|c|c|}
\hline & Model_1 & Model__ & Model_3 \\
\hline kapital & -0.096621 & -0.079016 & \\
\hline & $(0.00530)$ & $(0.00218)$ & \\
\hline Lrl & 0.07371 & & 0.002571 \\
\hline & $(0.00217)$ & & $(0.00138)$ \\
\hline Icr & -0.009742 & -0.000174 & \\
\hline Roe & $(0.000236)$ & $(0.000876)$ & \\
\hline & 0.124632 & 0.00122 & $0.1623^{*}$ \\
\hline Ros & $(0.05932)$ & $(0.00292)$ & $(0.0492)$ \\
\hline & -0.0943 & & -0.0833 \\
\hline Qli & $(0.129)$ & & $(0.0369)$ \\
\hline & $-0.138^{* *}$ & $-0.0825^{*}$ & -0.0893 \\
\hline turnover & $(0.0501)$ & $(0.0261)$ & $(0.0341)$ \\
\hline & 0.084582 & 0.025442 & \\
\hline cons & $(0.01595)$ & $0.000325)$ & \\
\hline & 0.256 & 0.193 & 0.212 \\
\hline $\mathrm{N}$ & $(0.182)$ & $(0.174)$ & $(0.258)$ \\
\hline $\mathrm{R}^{2}$ & 97 & 97 & 97 \\
\hline adj. R & 0.107 & 0.217 & 0.087 \\
\hline AIC & 0.039 & 0.069 & 0.051 \\
\hline BIC & 92.64 & 87.34 & 75.48 \\
\hline
\end{tabular}

As can be seen from table 3 , the insufficient number of regressors was significant in linear regression, and therefore this model is not indicative.

Another method of regression analysis of an imaginary or dummy variable involves building a logical model. We will use a multinomial logical model with the adjustment of standard errors by the White method to eliminate heteroscedasticity.

The method of assessing the model is the Maximum Likelihood Method (MLM), which provides unbiased, normally distributed and effective estimates, which guarantees the significance of the obtained model. To exclude multicollinearity of regressors, we build a 
correlation matrix of variables. In the studied variables, there is no problem of full multicollinearity, which is confirmed by the non-exceedance of the borderline indicator of 0.8 by the elements of the matrix. Table 4 presents the main ratios and statistics of the model.

Table 4. The results of the assessment of the logical regression model.

\begin{tabular}{|l|c|}
\hline & logit_model \\
\hline kapital & 0.10324 \\
\hline & $(0.0707)$ \\
\hline rrl & $-0.2208^{*}$ \\
\hline icr & $(0.0257)$ \\
\hline & $-0.0408^{* *}$ \\
\hline roe & $(0.00626)$ \\
\hline & $0.1202^{*}$ \\
\hline ros & $(0.0112)$ \\
\hline & -0.521 \\
\hline qli & $(3.635)$ \\
\hline & $-2.525^{* * *}$ \\
\hline turnover & $(0.932)$ \\
\hline & $0.03969^{* *}$ \\
\hline cut1 & $(0.00202)$ \\
\hline cons & \\
\hline & -1.978 \\
\hline N & $(0.0407)$ \\
\hline Pseudo R & 97 \\
\hline Wald chi & \\
\hline Prob $>$ chi $^{2}$ & 0.3848 \\
\hline Log-likelihood & 121.92 \\
\hline AIC & 0.0740 \\
\hline BIC & -327.166 \\
\hline
\end{tabular}

Most of the independent variables of the model are associated with the dependent variable at the significance level of more than five percent, which indicates the consistency of the model and the strong dependence of the probability of default on the factors under the study.

The Pseudo R2 indicator is above 35\%, which indicates the correctness of the compiled model. The Wald chi ${ }^{2}$ indicator tests the hypothesis that all regressors are equal to zero. In our case, this is rejected. We also have a high in modulo value of the logarithm of the likelihood function, which shows the probability of occurrence of the case described by the model.

Thus, the final regression model of dependence of the lessee's default probability on financial indicators is as follows:

$$
\text { PD }=0,103 * \text { kapital }-0,221 * \operatorname{lrl}-0,041 * \text { icr }+0,12 * \text { roe }-0,52 * \text { ros }-2,53 * \text { qli }+0,04 * \text { turnover }
$$

According to the obtained model, the quick liquidity ratio, return on sales, and financial leverage have the greatest impact on the default probability of the lessee in up to 12 months.

Thus, we built a regression model of dependence of the lessee's default probability on the basis of its financial statements, using the logistic function of the type

$$
F(z)=\frac{1}{1+e^{-z}}
$$




\section{Conclusion}

Using the obtained model, through the mathematical rounding of the obtained value, we get the final result, which takes the value 0 (high probability of default during the year) or 1 (low probability of default during the year). It should be noted that the above method excludes the subjective methods for assessing the potential client's solvency and is less labor-intensive in comparison with the scoring model and the method of expert assessment.

\section{References}

1. World Leasing Yearbook 2011 (Euromoney, L., 2011)

2. G.F. Amanollahi, Management Science Letters 6(3), 251-258 (2016) doi: 10.5267/j.msl.2016.1.003E.I.

3. O. Panfilova, V. Okrepilov, S. Kuzmina, MATEC Web of Conferences 170, 01032 (2018) doi:10.1051/matecconf/20181700103

4. A. Chernikova, S. Golovkina, S. Kuzmina, T. Demenchenok, IOP Conference Series: Earth and Environmental Science 90, 012045 (2017) doi: 10.1088/17551315/90/1/012045

5. M. Psillaki, I.E. Tsolas, D. Margaritis, European Journal of Operational Research 201(3), 873-881 (2010) doi: 10.1016/j.ejor.2009.03.032

6. E. Kichler, P. Haiss, SSRN Electronic Journal (2009) doi: 10.2139/ssrn.1343887

7. G.F. Amanollahi, J.B. Muhammad, Management Science Letters 6(1), 99-108 (2016) doi: $10.5267 /$ j.msl.2015.11.003

8. G. Newton, Bankruptcy and insolvency accounting, practice and procedure (Hoboken Wiley, N.J., 2009)

9. S. Agarwal, B.W. Ambrose, H. Huang, Y. Yildirim, Journal Of Financial An Quantitative Analysis 46(2), 553-584 (2011) doi: 10.1017/S0022109010000839

10. V. Agarwal, R. Taffler, Journal of Banking and Finance 32(8), 1541-1551 (2008) doi: 10.1016/j.jbankfin.2007.07.014 